\title{
THE IMPORTANCE OF THE REGIONS' ECONOMIC ACTIVITY EVALUATION IN RUSSIA,
} 2012-2016

KURCHENKOV, Vladimir Viktorovich* FETISOVA, Olga Vladimirovna

ORLOVA, Anastasiya Andreyevna

GLADKAYA, Elena Andreevna

\begin{abstract}
The article presents the systems of evaluating the regions' economic activity, which comprise various components. The regions' economic activity evaluation is done mostly through different rankings, which can generally be classified into: global and national. The analysis of the rankings' dynamics in 2012-2016 has shown that the Russian innovation activity is rising on the international level. Such a tendency is considered to be positive in the modern economic conditions, however the innovation activity needs to be accelerated. According to the national level rankings, there are 3 regions in the Russian Federation, which managed to apply their innovation potential better than other Russian Federation regions. Thus, various level rankings help defining the strengths and weaknesses of a region's innovation development, that in future can become the basis for leading coordinated innovation policy.

Key words: innovations, innovation activity, rating analysis, innovation activity evaluation methods.

JEL Codes: R10, 018, O31
\end{abstract}

\section{Introduction}

The innovation economy formation is an important competitive component and a topical task for all countries in the modern conditions. In this connection accelerating the regions' economic activity is a significant priority of the Russian long-term development in the near future.

The foreign countries' practice proves that the development of high technologies is an important factor of increasing the national economy's competitiveness. Owing to the innovative development orientation, many countries have become leaders in producing and commercializing the hi-tech production over the last years. China, the Republic of Korea, India and others can be referred to such countries. At the same time, the developed countries produce $80 \%$ of the innovation production (out of the total production volume) and approximately $70 \%$ of enterprises constantly introduce technological innovations. In Russia the share of science and innovations activity financing is rather low in comparison to other countries (Inshakov 2008, 2009).

The implementation of effective innovation policy in the country should be connected to the improving of the innovational activity of economic entities. An essential feature here is the elaboration of a complex measures system, which should include measures on developing the region's innovation infrastructure, forming the labour potential for successful innovation activity, attracting external investments and etc.. In turn, the innovation development policy should be guided by the evaluation system of innovation activity, which is to provide the coincidence between the innovation activity goals and

\footnotetext{
* Vladimir Viktorovich KURCHENKOV, Doctor of Economics, Professor, E-mail: kurchenkov@ volsu.ru; Olga Vladimirovna FETISOVA, Doctor of Economics, Professor, E-mail: fetissova@ volsu.ru; Anastasiya Andreyevna ORLOVA, PhD, Associate Professor, E-mail: oponir@volsu.ru; Elena Andreevna GLADKAYA, PhD, Associate Professor, E-mail: gea@volsu.ru, Department of State and Municipal Administration, Volgograd State University, Volgograd, Russian Federation .
} 
results of the innovation activity in terms of the main sustainable socio-economic development of the regional economies.

Besides, a set of indicators, allowing to evaluate the innovation activity level is an important condition for managing the region's economy (Antonenko 2014), (Plotnikov et al. 2015). This issue is discussed by local and foreign scientists, although several aspects still remain uncovered. (Bobrov 2016), (Krainov 2014), (Molchanov and Petergova 2015), (Pavlycheva 2016). In particular, the level of the innovations' relativity, the innovations defining and classifying by their novelty level still lack sufficient research. In addition to it, the official statistics does not take into consideration the so-called latent innovations, which sometimes have a very high integration level. And, finally, there are no methodic approaches to determining the innovation activity integral indicator, taking into account diverse types and groups of innovations regarding various criteria, including the absoluteness and relativity (Kurchenkov 2011, 2013).

\section{Regions' innovation activity methods}

The article presents the systems of evaluating the regions' economic activity, which comprise various components. The regions' economic activity evaluation is done mostly through different rankings, which can generally be classified into: global and national. Table 1 presents the most famous global and national rankings. Various rankings use different evaluation methods, as a consequence, countries take various positions (Table 1). Table 2 shows two global rankings, reflecting the global innovation activity.

Table 1. Regions' innovation activity ranking

\begin{tabular}{|c|c|c|}
\hline $\begin{array}{l}\text { Type of } \\
\text { ranking }\end{array}$ & Name & Brief characteristics \\
\hline \multirow[t]{2}{*}{$\begin{array}{l}\pi \\
\frac{\pi}{0} \\
0 \\
0\end{array}$} & $\begin{array}{l}\text { Global Innovation } \\
\text { Index }\end{array}$ & $\begin{array}{l}\text { The ranking comprises } 82 \text { indicators, reflecting the } \\
\text { potential, efficiency and innovation activity framework } \\
\text { conditions. The ranking includes such parameters as } \\
\text { institutions, human capital, scientific studies, } \\
\text { infrastructure, domestic market development, the state } \\
\text { of business, the development of technologies and } \\
\text { knowledge economy, creativity results. }\end{array}$ \\
\hline & $\begin{array}{l}\text { Bloomberg } \\
\text { Innovation Index }\end{array}$ & $\begin{array}{l}\text { The ranking is calculated basing on } 7 \text { indicators: R\&D } \\
\text { studies costs, efficiency, hi-tech companies concentration, } \\
\text { higher education prevalence, value-added goods, the } \\
\text { number of patents and researchers registered. }\end{array}$ \\
\hline \multirow[t]{2}{*}{ 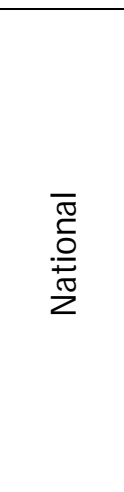 } & $\begin{array}{l}\text { Regions innovation } \\
\text { activity ranking } \\
\text { (NAIRIT) }\end{array}$ & $\begin{array}{l}\text { The idea and methodology were elaborated by the } \\
\text { Innovations and Information Technologies National } \\
\text { Association, basing on the world analogues' examples } \\
\text { (primarily the «European Innovation Scoreboard»). A } \\
\text { system of quantitative indicators is used as a basis for } \\
\text { analyzing the regions' innovation activity. The criteria } \\
\text { elaborated in the EIS framework for evaluating the } \\
\text { European countries' innovation development and } \\
\text { adapted in accordance with the national specificity and } \\
\text { statistic data search opportunities. }\end{array}$ \\
\hline & Russian Federation & The ranking of the Russian Innovative Regions \\
\hline
\end{tabular}




\begin{tabular}{|l|l|l|}
\hline $\begin{array}{l}\text { Development } \\
\text { Ranking for the } \\
\text { Manitoring and } \\
\text { Purposes n(AIRR) }\end{array}$ & $\begin{array}{l}\text { regions' innovative development. Special attention is paid } \\
\text { to analyzing the Association members' positions, the } \\
\text { reasons of their rotation in the final ranking and the } \\
\text { components of its sub-rankings. }\end{array}$ \\
\hline $\begin{array}{l}\text { Russian Federation } \\
\text { Innovative } \\
\text { Development } \\
\text { Ranking (the HSE) }\end{array}$ & $\begin{array}{l}\text { The study carried out by the Higher School of Economics } \\
\text { bases on a system of indicators, describing the socio- } \\
\text { economic conditions of the innovation activity, the } \\
\text { scientific-technical potential, innovation activity level, } \\
\text { regional innovation policy quality. }\end{array}$ \\
\hline $\begin{array}{l}\text { The Main } \\
\text { Innovation Activity } \\
\text { Indicators Federal } \\
\text { State Statistics } \\
\text { Service) }\end{array}$ & $\begin{array}{l}\text { Providing the compatibility with the international } \\
\text { standards (The Oslo Manual, united investigation } \\
\text { programme - EUCIS) }\end{array}$ \\
\hline
\end{tabular}

Resource: composed by the authors

Table 2. The top-20 countries in global rankings in 2016

\begin{tabular}{|c|c|c|}
\hline \multirow{2}{*}{ Position } & \multicolumn{2}{|c|}{ Title of ranking } \\
\hline & Global Innovation Index & Bloomberg Innovation Index \\
\hline 1 & Switzerland & South Korea \\
\hline 2 & Sweden & Germany \\
\hline 3 & Great Britain & Sweden \\
\hline 4 & the USA & Japan \\
\hline 5 & Finland & Switzerland \\
\hline 6 & Singapore & Singapore \\
\hline 7 & Ireland & Finland \\
\hline 8 & Denmark & the USA \\
\hline 9 & the Netherlands & Denmark \\
\hline 10 & Germany & France \\
\hline 11 & South Korea & Israel \\
\hline 12 & Luxemburg & Russia \\
\hline 13 & Iceland & Austria \\
\hline 14 & Hong-Kong (China) & Norway \\
\hline 15 & Canada & Ireland \\
\hline 16 & Japan & Belgium \\
\hline 17 & New Zealand & Great Britain \\
\hline 18 & France & the Netherlands \\
\hline 19 & Australia & Canada \\
\hline 20 & Austria & Australia \\
\hline
\end{tabular}

Source: Global Innovation Index (2017), Bloomberg Innovation Index (2017)

When composing the rankings in Table 1 below various methods have been applied, that-can affect the countries' distribution. We shall consider 2 main rankings on the global innovation activity, shown in Table 2 below.

Analyzing the data in Table 26 it is clear that not all countries, ranked in the Top-20 by the Global Innovation Index are listed in the Bloomberg Innovation Index and vice versa. 
Thus, several countries, listed in the Global Innovation Index, such as Luxemburg, Iceland, Hong-Kong (China) and New Zealand are not mentioned in the Bloomberg Innovation Index. At the same time, being presented in the Bloomberg Innovation Index Israel, Russia, Norway and Belgium are not represented in the Global Innovation Index. Besides, the leading positions in one ranking do not guarantee leading positions in the second ranking due to different methods of calculation.

Since 2012 Russia has occupied various positions in global rankings (see Table 3).

Table 3. Russia's positions in global rankings

\begin{tabular}{|l|c|c|c|c|c|}
\hline \multirow{2}{*}{\multicolumn{1}{|c|}{ Title of ranking }} & \multicolumn{5}{|c|}{ Years } \\
\cline { 2 - 6 } & 2012 & 2013 & 2014 & 2015 & 2016 \\
\hline Global Innovation Index & 51 & 62 & 49 & 48 & 43 \\
\hline Bloomberg Innovation Index & 22 & 14 & 18 & 14 & 12 \\
\hline
\end{tabular}

Resource: composed by the authors

Table 3 proves that since 2013 Russia has been improving its position in the Global Innovation Index and finally took the $43^{\text {rd }}$ rank in 2016. Since 2014 Russia has risen from the $18^{\text {th }}$ (2014) rank to the $12^{\text {th }}$ (2016).

Russian Federation has done the innovations statistic analysis since 1994. We shall consider Russia's innovation activity by the examples of several regions (Tables 4, 5, 6).

Table 4. Regions' innovation activity ranking according to the NAIRIT

\begin{tabular}{|c|c|c|c|}
\hline \multicolumn{2}{|r|}{ Extremely high innovation activity } & \multicolumn{2}{|r|}{ High innovation activity } \\
\hline 1 & Moscow & 13 & Penza Oblast \\
\hline 2 & The Republic of Tatarstan & 14 & Altai Krai \\
\hline \multicolumn{2}{|r|}{ High innovation activity } & 15 & Sverdlovsk Oblast \\
\hline 3 & Saint-Petersburg & 16 & Tver Oblast \\
\hline 4 & Samara Oblast & 17 & Khabarovsk Krai \\
\hline 5 & Nizhniy Novgorod Oblast & 18 & Vladimir Oblast \\
\hline 6 & Tomsk Oblast & 19 & Kaluga oblast \\
\hline 7 & Krasnodar Krai & 20 & Perm Krai \\
\hline 8 & Moscow Oblast & 21 & Krasnoyarsk Krai \\
\hline 9 & Novosibirsk Oblast & 22 & Saratov Oblast \\
\hline 10 & Tyumen Oblast & 23 & Yaroslavl Oblast \\
\hline 11 & The Republic of Bashkortostan & \multicolumn{2}{|r|}{ Medium innovation activity } \\
\hline 12 & Chelyabinsk Oblast & 45 & Volgograd Oblast \\
\hline
\end{tabular}

Source: NAIRIT (2015)

Table 4 presents a fragment from the ranking made up by the Innovations and Information technologies National Association. The leading positions in this ranking belong to Moscow, the Republic of Tatarstan and Saint-Petersburg. Volgograd Oblast occupies the $45^{\text {th }}$ rank and is among the regions with medium innovation activity.

Russia's regions' innovative development ranking is annually composed by the Higher School of Economics. The ranking for the year 2014 was made up in 2016 due to the fact that experimental data is collected with a certain lag. The innovative development aspects are properly analyzed, however their interconnection cannot be observed. As we can see 
in Table 6 , the Republic of Tatarstan occupies the leading position by the total ranking and the innovation policy quality. The Republic of Mordovia takes the $1^{\text {st }}$ place by the innovation activity, Moscow has the best socio-economic conditions, while Volgograd has taken only the $2^{\text {nd }}$ place in the overall ranking.

Table 5. Russia's innovative regions ranking RIRA

\begin{tabular}{|l|l|}
\hline \multicolumn{2}{|c|}{ Strong Innovators } \\
\hline 1. & Moscow \\
\hline 2. & Saint-Petersburg \\
\hline 3. & The Republic of Tatarstan \\
\hline 4. & Tomsk Oblast \\
\hline 5. & Novosibirsk Oblast \\
\hline 6. & Kaluga oblast \\
\hline 7. & The Republic of Bashkortostan \\
\hline 8. & Nizhniy Novgorod Oblast \\
\hline 9. & Moscow Oblast \\
\hline 10. & Samara Oblast \\
\hline 11. & Krasnoyarsk \\
\hline \multicolumn{2}{|c|}{ Medium and weak innovators } \\
\hline 51. & Volgograd Oblast \\
\hline
\end{tabular}

Source: Russia's innovative regions (2016)

The leading positions in the ranking made up by the Russia's Innovative Regions Association belong to Moscow, Saint-Petersburg and the Republic of Tatarstan (Table 5). Volgograd Oblast has taken the 51st rank thus being among the medium and weak innovators

Table 6. Russia's regions' innovative development ranking

\begin{tabular}{|c|l|c|}
\hline Position & \multicolumn{1}{|c|}{ Region } & Index \\
\hline 1 & The Republic of Tatarstan & 0,5625 \\
\hline 2 & Moscow & 0,553 \\
\hline 3 & Saint-Petersburg & 0,5413 \\
\hline 4 & The Republic of Mordovia & 0,493 \\
\hline 5 & Kaluga oblast & 0,4812 \\
\hline 6 & Nizhniy Novgorod Oblast & 0,4749 \\
\hline 7 & Tomsk Oblast & 0,4652 \\
\hline 8 & The Chuvash Republic & 0,4645 \\
\hline 9 & Khabarovsk Krai & 0,4498 \\
\hline 10 & Penza Oblast & 0,4411 \\
\hline 32 & Volgograd Oblast & 0,3627 \\
\hline
\end{tabular}

Source: Russia's regions' innovative development ranking (2016)

Summing up the results of national rankings (Tables 4,5,6), it seems clear that Moscow, Saint-Petersburg and the Republic of Tatarstan have managed to take the leading positions owing to their innovation potential (infrastructure, geographical location, resources). These regions can even be called Russian economy's leaders, which set the 
grounds for developing investment standards and are the driving forces of the federal development programs.

However, it is worth pointing out that the indicators applied in the statistics do not allow making the comparative analysis of the innovation activity fully. In particular, the statistics doesn't reflect the volume of the research, carried out for the regions' or economic entities' own use. In general, the infrastructure of regional innovation system is not the object of statistical accounting (Deinega, 2008). In this regard, along with the traditional statistic indicators, we consider it necessary to introduce additional, defining the innovation activity resource potential and the parameters of its temporary change.

According to this method, it is necessary to introduce the aggregated (integrated) relative indicators, which allow to compare the main industrial and agricultural sectors by their innovation activity in order to make the comparative analysis more fundamental. Additionally, it is worth making a complex comparison of the innovation activities of economic entities', group them into 3 groups: innovative active, moderately active and low active (Fig. 1). And finally, these indicators help to compare the overall Russian innovation activity level to the average innovation activity level in the South Federal District regions.

As it is shown in Figure 1, it is considered appropriate to define 3 indicators levels in order to evaluate the enterprises' innovation activity. The 1st level includes traditional indicators (by the innovation types), applied in the statistics. The indicators of the 2nd level reflect the relative weight value of each 1 st level indicator. The 3rd level implies adding the 2nd level indicators by using the conversion coefficient. The final integral indicator can serve as the basis for comparing the region's enterprises' innovation activity with the innovation activity of the enterprises in other regions. The given innovation activity indicators are evaluated as S1, S2, S3 ...Sn and show the share of a certain innovation type.

The main innovation types are:

a) product innovations, b) technological innovations, c)organization innovations,

d) marketing innovations, e)processing innovations.

\section{Indicators}

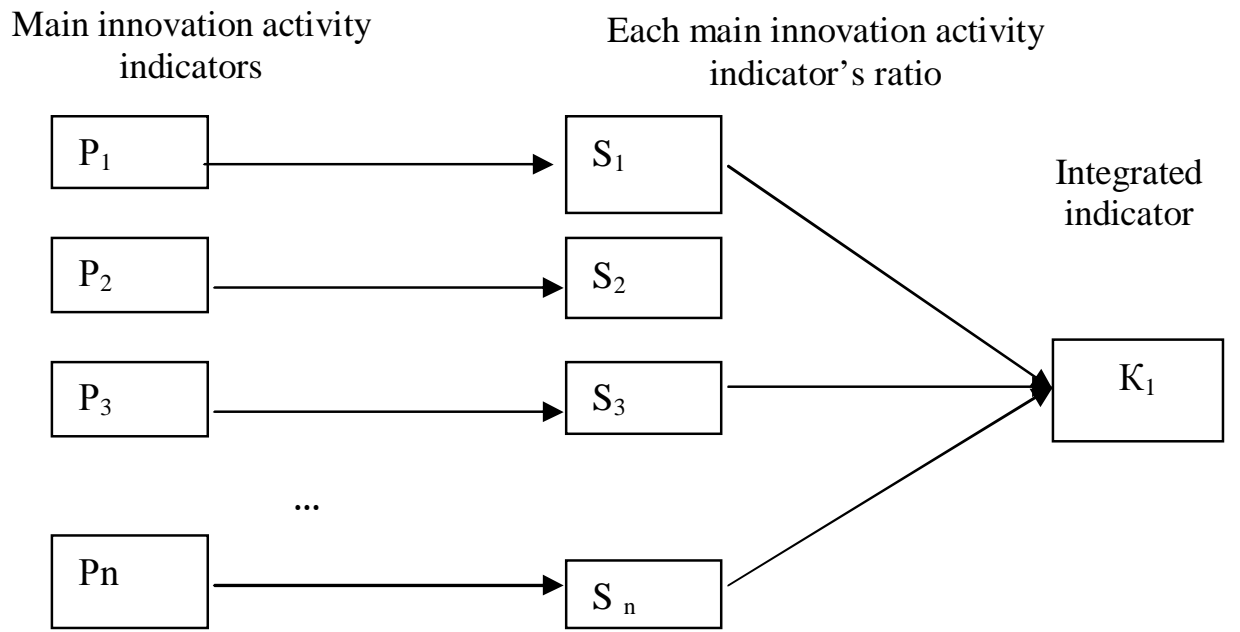

Figure 1. The main region's enterprises' innovation activity analysis indicators

Resource: composed by the authors 
The integral indicator is calculated by the following formula:

where,

$$
\mathrm{K} 1=\mathrm{S}_{1} \mathrm{x}_{1}+\mathrm{S}_{2} \mathrm{X}_{2}+\mathrm{S}_{3} \mathrm{X}_{3} \ldots .+\mathrm{S}_{\mathrm{n}} \mathrm{X}_{\mathrm{n}}
$$

$\mathrm{S}_{1}, \mathrm{~S}_{2}, \mathrm{~S}_{3} \ldots \mathrm{S}_{\mathrm{n}}$ are innovations weight share by the main types.

$\mathrm{x}_{1}, \mathrm{x}_{2}, \mathrm{x}_{3} \ldots \mathrm{x}_{\mathrm{n}}$ are correlation coefficients.

However, despite the logics of the suggested system of evaluating the innovation activity, it needs to be improved, because it doesn't take into account a set of fundamental moments. First of all, the suggested indicators are not compatible with the indicators of other countries, that is why the comparative analysis of the innovation activity in other regions can barely be conducted. Secondly, the official statistics does not reflect the inevident innovations, which are not recorded officially. Such innovations include the enhancing innovations, which are implemented immediately at a workplace. Thirdly, the innovations are traditionally divided into radical, combined and enhancing innovations, which are variously influencing the enterprise's competitiveness and, consequently, reflect its innovation activity. And fourthly, another important aspect of calculating the innovation activity in the region is the degree of the innovation's relativity (Kurchenkov, 2013).

In fact, an innovation can be viewed and evaluated both within an enterprise and within a region's (country's) economic sector. The evaluation of the innovation's relativity can have a multi-level system of indicators- the so-called indexes of the innovations' relativity of the 1st, 2nd and 3rd rank (Kurchenkov, 2013). After that the relativity indexes are added in accordance with the correlation coefficients and afterwards the final integral relativity index is calculated. This integral relativity index is used for calculating a region's innovation potential and innovation activity. The analysis of the modern innovation activity shows that the most part of innovations, implemented by the enterprises, is relative, i.e. it's not the first time they are applied. At the same time the relativity index of the 1 rank is rather high in comparison to the corresponding index in the highly developed countries. In particular, up to $80 \%$ of the Volgograd Oblast enterprises' innovation activity is determined by purchasing the up to date foreign equipment, the analogues of which are already being used in other countries.

The indicators of the innovation relativity can be defined by to the following ranks:

R1- an absolute indicator of the innovation activity, reflecting the innovations, elaborated and used by only one enterprise, what makes this enterprise highly competitive for a long period of time.

R2 - the innovation activity relativity indicator of the 1st rank, reflecting the innovation elaborations, used in one or several national economy sectors.

R3- the innovation activity relativity indicator of the 2nd rank, reflecting the innovation elaborations, which are widely used all over the world.

Generally, all innovation elaborations types can be found on an enterprise, however their innovation activity can be evaluated on the basis of their correlation in shares and absolute and domination of relative innovations of the 1st rank. 
Each indicator is a relative figure and can be the ratio of the innovation elaborations volume of this or that rank to the total volume of innovations elaborations of an enterprise over the reporting period. For example,

$$
\begin{aligned}
& \mathrm{Q} 1=\mathrm{R} 1 / \mathrm{In} ; \\
& \mathrm{Q} 2=\mathrm{R} 2 / \mathrm{In} ; \\
& \mathrm{Q} 3=\mathrm{R} 3 / \mathrm{In} ;
\end{aligned}
$$

where, $R_{1}, R_{2}, R_{3}$ - innovation elaborations of various ranks, depending on their relativity degree. In - the overall volume of innovation elaborations over the reporting period.

The correlation of these indicators allows to group the economic entities by their innovation activity level, taking into account the innovations relativity criterion (Table 6).

Table 6 . The levels of the economic entities' innovation activity, according to the innovations relativity degree

\begin{tabular}{|r|l|c|}
\hline № & Indicators correlation & Innovation activity level \\
\hline 1 & $\mathrm{Q}_{1}+\mathrm{Q}_{2} \geq \mathrm{Q}_{3}$ & high \\
\hline 2 & $\mathrm{Q}_{1}+\mathrm{Q}_{2}=\mathrm{Q}_{3}$ & medium \\
\hline 3 & $\mathrm{Q}_{1}+\mathrm{Q}_{2} \leq \mathrm{Q}_{3}$ & low \\
\hline
\end{tabular}

Resource: composed by the authors

As it is shown in Table 1, if the share of absolute and relative innovations of the 1st rank is high enough with respect to the innovations of the $2^{\text {nd }}$ rank, then an enterprise's innovation activity level is assumed to be high. On the contrary, if most of an enterprise's innovations are the innovations of the $2^{\text {nd }}$ rank then an enterprise's innovation activity level is supposed to be low.

\section{Results}

The investigation of the innovative entities' technological innovations activity is to be conducted by federal districts and the Southern Federal District in particular (Fig. 2 and 3 ). The cumulative costs of technological innovations (product and process) in Russia amount 1 trillion 203 billion 638 million 84 thousand 300 rubles (Innovations 2016).

As you can see in Figure 2, the Central Federal District bore significant costs on technological innovations, 411 billion 465 million 853 thousand 500 rubles (34,19\% from the cumulative costs of technological innovations in Russia). The Volga Federal District takes the second place- 300 billion 124 million 474 thousand 800 rubles $(24,93 \%)$, Siberian Federal District takes the third place with 140 billion 231 million 792 thousand 600 rubles $(11,65 \%)$. These regions are followed by the Ural Federal District $(9,98 \%)$, North-Western Federal District (7,3\%), Southern Federal District (5,82\%), Far Eastern Federal District (5,59\%), North-Caucasus Federal District (0,49\%) and Crimean Federal District (0,05\%).

The Southern Federal District occupies the 6 place in this ranking and allocates 70 billion 070 million 63 thousand 300 rubles. Figure 3 shows how this allocation was distributed.

As you can see in Figure 3, Rostov Oblast bore the bigger of technological innovation costs- 31 billion 609 million 919 thousand rubles. The Republic of Kalmykia allocates 4 
million 361 thousand 500 rubles, whereas Volgograd Oblast takes the $2^{\text {nd }}$ place by the technological innovations costs in the Southern Federal District- 30 billion 705 million 155 thousand 900 rubles.

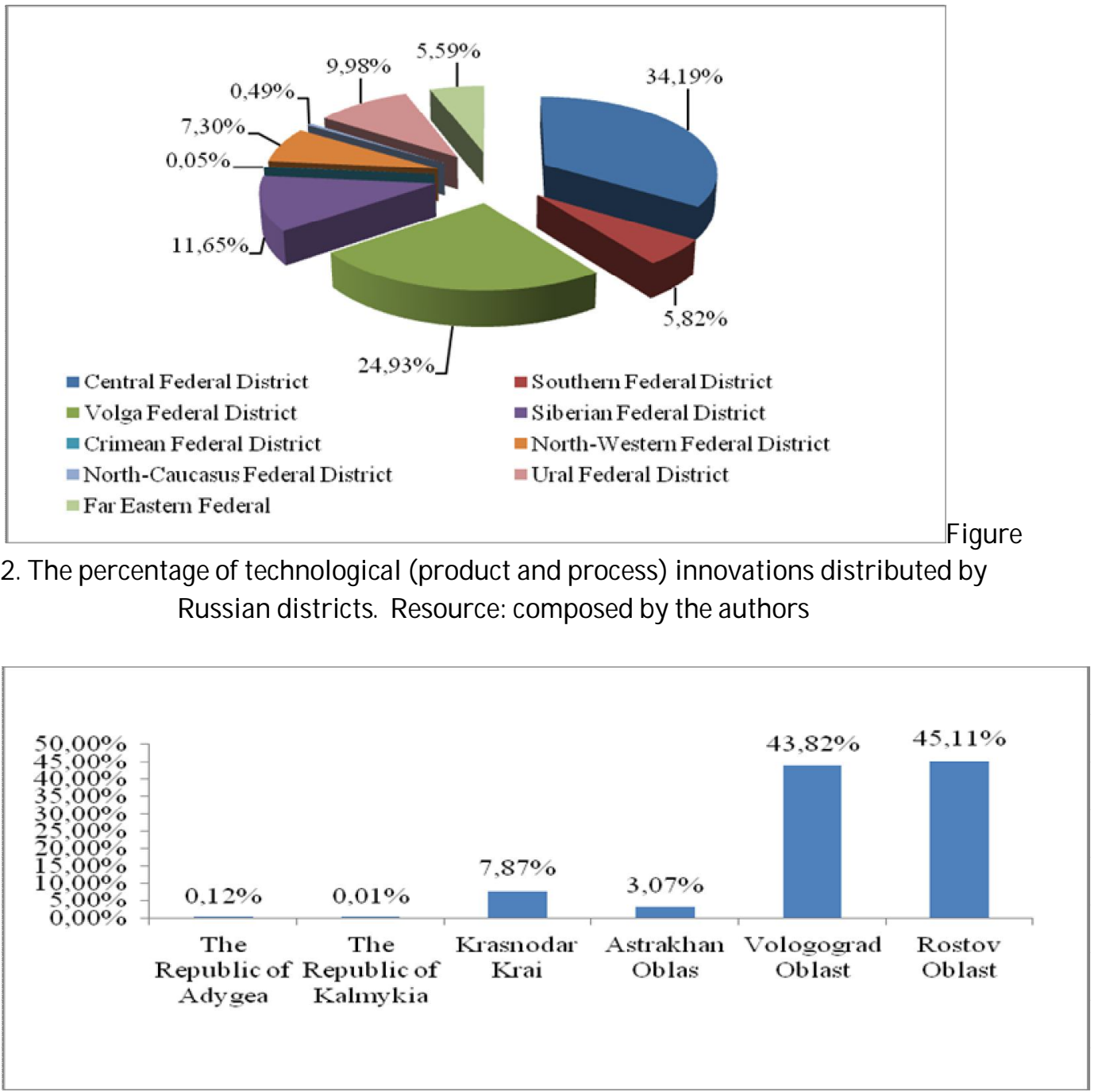

Figure 3. The percentage of technological (product and process) innovations in the Southern Federal District. Resource: composed by the authors

The integral indicators method is rather popular for evaluating the region's economic entities' innovation activity level. There are very many approaches and integral indicators (Duplenko 2016), (Krainov 2014), (Grabowska 2014), (Zedtwitz 2016). Besides, despite the diversity of approaches to calculating the innovation activity integral indicator, the main principle remains universal and implies using the given figures with their further functional aggregation. 
The application of this method is complicated by the absence of corresponding statistical data. However, the study can be carried out empirically by surveying the enterprises and applying the expert evaluation method. According to this approach Volgograd Oblast's study results are as follows (Table 7).

Table 7. Economic entities' innovation activity levels in accordance with the innovations' relativity degree

\begin{tabular}{|l|l|l|l|}
\hline № & $\begin{array}{c}\text { Innovations' relativity } \\
\text { indicators correlation }\end{array}$ & $\begin{array}{l}\text { Innovation activity } \\
\text { level }\end{array}$ & South Federal District regions \\
\hline 1 & $\mathrm{Q}_{1}+\mathrm{Q}_{2} \geq \mathrm{Q}_{3}$ & high & Krasnodar Krai, Rostov Oblast \\
\hline 2 & $\mathrm{Q}_{1}+\mathrm{Q}_{2}=\mathrm{Q}_{3}$ & medium & $\begin{array}{l}\text { Volgograd Oblast, Astrakhan } \\
\text { Oblast }\end{array}$ \\
\hline 3 & $\mathrm{Q}_{1}+\mathrm{Q}_{2} \leq \mathrm{Q}_{3}$ & low & $\begin{array}{l}\text { The Republic of Kalmykia, } \\
\text { The Republic of Adygea }\end{array}$ \\
\hline
\end{tabular}

Resource: composed by the authors

Table 7 illustrates that the main part of innovations, applied by the enterprises in Volgograd Oblast are the relative innovations of the 1st and 2nd rank, which is $90 \%$ in total and that reduces the overall innovation activity level.

Analyzing the decrease of innovation activity in Russian regions and Volgograd Oblast in particular, it is necessary to analyze its reasons.

The main reasons of the Russian enterprises' low innovation activity in the modern environment are:

- the insufficient amount of the enterprises' investment resources. Thus, around $98 \%$ of innovation costs are the enterprises' own money, whereas in foreign countries the innovation costs are the money from the sate or venture funds [6; 14];

- a strong competitive pressure from foreign producers on the internal markets;

- the absence of an innovation development united program and a system for supporting innovation-active enterprises on the state level;

- new enterprises owners show indifference to develop and modernize the production;

- legal exposure of local enterprises from the officials, municipalities and criminal arbitrariness (raiding);

- innovation activity infrastructure and information support system's underdevelopment.

An important factor in improving of innovative activity of economic entities is market competition. As F.Hayek (1989) noted, competition is forcing companies to apply brandnew combinations. Thus, innovation activity is an important condition for improving the company's competitiveness (Lebedeva 2010).

\section{Conclusion}

The innovation activity rankings of various levels should have the information and stimulating functions. These rankings help discover strengths and weaknesses of a region's innovation development and provide dynamic innovation development. 
The key problem of evaluating the innovation activity in Russia is that the innovations are developed from the supply side, i.e. new development institutions, scientific centres and hi-tech production are established. Consequently, innovation rankings register infrastructural changes: development of technoparks, technological centres, finance organizations, supporting the hi-tech production output and etc.. But the demand side remains unexplored. At the same time the situation in the US is vice versa, when the innovations development institutions arose only when they were in demand.

The regions' increasing innovation activity is top priority of Russia's economic progress, as innovations bear some certain positive effects. Particularly, implementing innovations helps enhancing production efficiency, improve working conditions, satisfy the demand for quality goods, improve the environment. However, Russian enterprises lack innovation activity nowadays. Innovation activity deficient financing, low competitiveness level in regions and the absence of these enterprises' managers' motivation are the reasons of the innovation activity lack.

According to the analysis of the reasons for the Russian enterprises' low innovation activity, we can define the main directions of enhancing it:

- Increasing investment resources volume intended for innovation activity;

- Improving the enterprises' innovation processes management system;

- $\quad$ Developing the legal framework of intellectual property protection;

- $\quad$ Forming the enterprises' long-term innovative development strategy;

- Optimizing the innovation process's structure and by innovation types and innovation activity directions;

- Intensifying the forms of state support and state innovation activity regulation on local industrial enterprises;

- $\quad$ Developing the motivation system to encourage the production and management personnel for innovation activity;

- $\quad$ Developing the innovation infrastructure and innovation information support.

Another important thing is to create a comprehensive innovation activities analysis and evaluation system in the region, which using multilevel integrated indicators and indicators reflecting the innovation relativity in addition to traditional statistical indicators.

\section{References}

Bobrov, V.S. (2016). The Problems of Developing Small Enterprises' Innovative Activity. Naukapark. No. 5, (46), p. 22-25.

Deinega, V.G. (2008). National Innovation System' Regional Structure Formation Features. A Region's Economic Development: Problems, Searches, Perspectives: Yearbook, Issue. 9. Volgograd: VolSU Publishing House, p. 273-289.

Duplenko, N.G, Smirnova, O.S. (2016). Industry and Regional Analysis of the Russian Enterprises' Innovation Activity. I. Kant Baltic Federal University Science Journal. I. Kant. Series: Humanities And Social Sciences, No. 2, p. 85-95.

Innovations (2016). URL: http://www.gks.ru/wps/ wcm/connect/rosstat_main/rosstat / ru/ statistics/ science and innovations/ science/ \#

Kiselev, V.N. (2010). Russian Federation Regions' Innovation Activity Comparative Analysis. Innovations, No. 4 (138). p. 17-24. 
Krainov, A.E. (2014). Innovation activity as an Enterprise's Management System Formation Factor. Modern Economics: Expertise, problems and development perspectives, № 3, pp. 77-81.

Kurchenkov V.V. (2013). Enterprises' Innovation Activity in Terms of Global Competition. Innovations, №5 (175), p. 60-65.

Kurchenkov, V.V., Ovshinov, S.A. (2011) Definition of an Industrial Enterprise's Production Modernization Optimal Variant. Volgograd Institute of Business Science Journal . Business. Education. Law, No. 3 (16), p. 43-50.

Lebedeva, N.N. (2010). Enterprises' Innovation Activity as Their Competitiveness Condition. Institutional Research Journal, Volume 2., No. 4, p. 15-21.

Mochalova, K.M., Petergova, A.V. (2015). Industrial Enterprises Innovation Activity Development Directions. Moscow State Technical University Izvestiya MAMI. T. 5, No. 4 (26), pp. 237-241.

National Association of Innovation and Information Technology Development (NAIRIT) (2015) URL: http:/ / www.nair-it.ru/ news/ 31.07.2015/ 461

Pavlycheva, A.V. (2016) Russian Enterprises' Innovation Activity. Novainfo.ru. N 1, No. 46, p. 67-72.

Russian Federation Regions' Innovation Development Ranking (2016) URL: https:// www.hse.ru/primarydata/ rir2016

Russia's Innovative Regions Ranking (2016) URL: http://iregions.org/images/files/ presentations/AIRR 26.12.pdf.

Volgograd Oblast Innovative Development Strategy until 2025 : monography / Authors Team Chief O.V. Inshakov. Volgograd: VolSU Publishing house, 2009. - 224 p.

Volgograd Oblast Innovative Development Strategy until 2025 : monography / Authors Team Chief O.V. Inshakov. Volgograd: VolSU Publishing house, 2008. - 356 p.

Hayek F. (1989). Competition as the Opening Procedure. World Economy and International Relations, № 12, p. 6-14.

Antonenko, I. (2014). Innovation Development Sectoral Trajectories Of The South Russian Regions. Regional and Sectoral Economic Studies. Vol. 14-2, pp. 31-34.

Bloomberg Innovation Index (2017) URL: https:/ / www.bloomberg.com.

Global Innovation Index (2017) URL: www.globalinnovationindex.org.

Grabowska, M. (2014). Selected directions in analysis of innovative activities in enterprises. Applied Mechanics and Materials, T. 718, pp.50-55.

Plotnikov, V., Fedotova, G., Popkova, E., Kastyurina, A. (2015). Harmonization of Strategic Planning Indicators of Territories' Socioeconomic Growth. Regional and Sectoral Economic Studies, Vol. 15-2, pp. 105-114.

Rubino, F.E., Rija, M., Bronzetti, G., Sicoli, G., Tenuta, P. (2016) An innovative model for a sustainability report in no-profit organizations. Source of the DocumentInternational Journal of Learning and Intellectual Capital, N 13 (2-3), pp. 119-134

Zedtwitz, M. A., Corsi, S.,Soberg, P.V., Frega, R. (2016). Typology of reverse innovation. Journal of Product Innovation Management, N 32 (1), pp. 12-28.

Revista Galega de Economia: http:/ / WWW.usc.es/ econo/ RGE/ benvidag.htm https:/ / ideas.repec.org/ s/ sdo/ regaec.html 